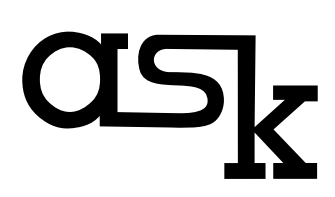

Research \& Methods

ISSN 1234-9224, e-ISSN 2544-0799

Vol. 28 (1, 2019): 21-42

The Ohio State University Libraries

Columbus, Ohio, USA

Institute of Philosophy and Sociology

Polish Academy of Sciences, Warsaw, Poland

www.askresearchandmethods.org

https://doi.org/10.18061/ask.v28i1.0002

\title{
Between fallacy and feasibility? Dealing with the risk of ecological fallacies in the quantitative study of protest mobilization and conflict
}

\author{
Leila Demarest \\ Leiden University \\ Arnim Langer \\ University of Leuven \\ Bart Meuleman \\ University of Leuven
}

\begin{abstract}
In recent years, the quantitative study of conflict has increasingly focused on small-scale and/or localized conflicts in the developing world. In this paper, we analyze and critically reflect upon a major methodological shortcoming of many studies in this field of research. We argue that by using group- or macro-level empirical data and modelling techniques, while at the same time theoretically underpinning observed empirical associations with individual-level mechanisms, many of these studies risk committing an ecological fallacy. The individual-level mechanism on which many studies rely concerns the presence of grievances which mobilize people to participate in contentious politics. This motivational approach was also present in early studies on protest mobilization in Western societies, which often relied on similar research designs. However, subsequent advances in this literature and the use of methods that were targeted more directly at the individual level uncovered that grievances alone cannot explain mobilization and that organizational capabilities and complex psychological mechanisms of belonging also form part of the puzzle. While drawing on conflict events as well as survey data from Africa, we demonstrate empirically that here, as well, inferring micro-level relations and dynamics from macro-level empirical models can lead to erroneous interpretations and inferences. Hence, we argue that to improve our understanding of conflict mobilization in the developing world, especially for conflicts with low levels of violence, it is necessary to substantially expand our methodological toolbox beyond macro-level analyses.
\end{abstract}

Key words: ecological fallacy, methodological individualism, conflict studies, social movements, protests 


\section{INTRODUCTION}

In recent years, the conflict literature has increasingly focused on relatively smallscale forms of conflict, such as communal conflicts, protests and riots occurring in the developing world. Many studies in this field have presented empirical evidence which seems to suggest that these forms of conflict - sometimes collectively referred to as "social disorder events" - are driven by resource scarcity dynamics and considerations (e.g. Hendrix \& Salehyan, 2012; Weinberg \& Bakker, 2015). Methodologically, it is noteworthy that most social disorder studies tend to use individual-level theory to substantiate relations between group- or macro-level empirical variables. In particular, grievance-based theories, usually drawing on Gurr's (1974) concept of relative deprivation, are often used to theoretically underpin the empirical link between different scarcity measures and the incidence or risk of a particular social disorder event occurring.

The empirical strategy of using macro-level data and modelling approaches is similar to that used in many quantitative studies which aim to explain the determinants of the onset of civil war. These studies similarly tend to operationalize motivations by means of macro-level empirical data. A classic example in this respect is the study by Collier and Hoeffler (2002), in which they use macro-models to test the significance of greed versus grievance motivations in joining a rebellion or engaging in conflict. Arguably, the main reason why many quantitative civilwar studies have opted for this empirical strategy is the lack of reliable microlevel motivational data in civil-war settings. The practical difficulties of collecting individual-level data, coupled with a high risk of social desirability bias among rebel respondents may support the use of macro-level data in civil-war studies. However, by opting for this methodological approach, civil-war studies, such as Collier and Hoeffler's, risk committing an ecological fallacy.

The same ecological fallacy risk applies to many social disorder studies which rely on grievance theory to explain the causal mechanisms between a macro-level predictor and protest occurrence. Furthermore, while macro-level data may be useful in civil-war studies because they are potentially less prone to measurement error, this rationale is more difficult to uphold in the case of protest mobilization. Indeed, studies focusing on social movements and protest participation in Western contexts have often successfully used empirical methods that direct attention to the individual, such as interviews and surveys. By doing so, theories on protest dynamics have advanced substantially in this literature and solely grievance-based theories have been discredited as too simplistic. Individual-level data collection exercises on protest behaviour may still be challenging in developing contexts, but they constitute a realistic alternative to macro-level modelling approaches. 
Moreover, they offer the opportunity to overcome current ecological fallacy problems.

In this paper, we support this argument by analyzing the extent to which the risk of ecological fallacies is present among recent quantitative social disorder studies that specifically focus on explaining the emergence of protests and riots. In our empirical example, we focus on Africa because of the availability of both protest event datasets and a set of nationally representative surveys (i.e. Afrobarometer surveys) that contain a number of useful questions concerning people's protest and mobilization behavior. Although limited to Africa, we argue that the methodological issues we uncover have a wider appeal and importance. By relying on both macro-level empirical data on protest events as well as microlevel data on protest participation, we are able to show empirically that individuallevel inferences drawn from group- or macro-level empirical associations are not necessarily supported by actual micro-level data, and can therefore lead to ecological fallacies.

The paper proceeds as follows. In the next section, the mismatch between empirical data and theoretical models in recent social disorder studies is explored and contextualized within the larger conflict mobilization literature. In Section 3 , the notion of ecological fallacies and their presence in conflict studies is explained in more detail. In Section 4, the argument is illustrated empirically with concrete examples based on the social disorder literature. The empirical analyses demonstrate that there can be different dynamics and relations between key variables at both levels of analysis. Section 5 concludes and focuses specifically on both the theoretical strengths and data challenges implied by a methodological individualist perspective.

\section{ECOLOGICAL FALLACY RISKS IN SOCIAL DISORDER STUDIES}

\section{Current research on social disorder in the developing world}

In recent years, the focus of the quantitative conflict literature has increasingly shifted away from the study of civil wars towards more localized and small-scale conflicts and episodes (Bernauer \& Gleditsch, 2012) or so-called social disorder events (Hendrix \& Salehyan, 2012). One strand of this literature has focused in particular on how different scarcity factors can increase the risk of social disorder events in the developing world. For instance, Hendrix and Haggard (2015) have investigated the impact of international food price fluctuations on the risk of social disorder events in major African and Asian cities with regime type as an intermediary variable. The authors state that the "theoretical links between price movements and protest can be grounded in traditions of research on protest going 
back to the relative deprivation hypothesis" (Ibid., p.145, emphasis added). The authors thus use an individual grievance logic to theoretically underpin their empirical analysis. Similarly, Smith (2014) analyses urban social conflict in Africa and investigates whether domestic food price indices are causally associated with social unrest. He also assumes that mobilization is grievance-based when he states that "sharp unexpected increases may overwhelm coping mechanisms and increase grievances and the propensity to engage in unrest activities" (Ibid., p.682, emphasis added). Weinberg and Bakker (2015) use domestic-level food prices and investigate their effect on social unrest (i.e. riots, anti-government demonstrations, and government crises) based on the Cross-National Time-series Data Archive. They also mainly theorize their causal links via Gurr's relative deprivation theory: "our assumption is that food prices most directly affect the individual. Thus, we analyze the low-level events that are most likely to follow an economic grievance against the government" (Ibid., p.311, emphasis added). "Food prices [...] belong to this category of micro-economic indicators of well-being and provide a more direct assessment of the scarcity (or perceived scarcity) of food than any other indicator" (Ibid., p.312, emphasis added). Finally, Raleigh et al.(2015) investigate the relationship between disaggregated African market prices and violent conflict. In their paper they state that "the main mechanisms linking commodity prices to multiple forms of political violence is increased grievances due to scarcity, or opportunities for income generation" (Ibid., p.188, emphasis added).

A related set of studies has investigated the causal relationships between population growth, density and demographic composition, and the emergence of social disorder events. Urdal and Hoelscher (2012), for example, analyze the relationship between national-level youth bulges and social disorder events (e.g. demonstrations, strikes, riots, acts of terrorism) in major Asian and African cities. They argue that youth bulges may lead to economic exclusion and unemployment of youths (due to the effect on the labour market, among other things), which in turn may motivate people to participate in social disorder events and/or lower their opportunity costs of engaging in protests and riots. In another study, Buhaug and Urdal (2013) investigate the relationship between city level population growth and urban social unrest. In their theoretical section, they argue that "economic shocks in the form of recession or stagnation of the national economy [in combination with unmatched urban growth] could accentuate differences in and importance of economic privileges between individuals and groups, thus raising levels of dissatisfaction and grievances to the extent that it could spur violent reactions" (Ibid., p.5, emphasis added).

Social disorder events have also been linked to climatological issues and changes. Hendrix and Salehyan (2012) have investigated the relationship between rainfall variability and the occurrence of social disorder events in Sub-Saharan Africa. 
The authors stress the importance of individual grievances as a basis for conflict. In particular, they argue that rainfall decreases may lead to higher food prices, which in turn may cause discontent and social protests. However, the authors also consider other explanations for the possible increase in social conflicts: i.e. rainfall shocks may negatively affect public finances and diminish a state's capacity to deter social disorder events or diminish their capacity to distribute resources aimed at avoiding conflicts. Yeeles (2015) has also investigated the relationship between meteorological changes and social disturbances in 50 major cities in Africa and Asia between 1960 and 2006. He argues that there are several causal pathways between climate change and conflict, including macro-economic effects and the inability of the state to control conflict, scarcity-fuelled grievances, and increased anger and aggression due to exposure to higher temperatures.

In sum, it is common practice in the current literature on social disorder in the developing world to test theories that rest on individual-level processes by analyzing contextual-level indicators.

\section{Social disorder within the literature on contentious politics}

In terms of theory and statistical modelling, recent scarcity and social disorder studies largely mirror the approaches taken in most quantitative civil-war studies. Indeed, some of the scarcity measures, as well as control variables, seem to be directly derived from past studies on armed conflict (e.g. rainfall variability (Miguel, Satyanath \& Sergenti, 2004) and youth bulges (Urdal, 2004)). Yet, as many studies focus on (violent) protest mobilization, one can also draw insights from the social movement literature, which although often focused on Western contexts, holds important theoretical and methodological insights to understand conflict mobilization in the developing world.

When interpreted against the background of major theoretical developments in the social movement literature, it emerges that current social disorder studies correspond strongly to early motivational approaches to the study of conflict that arose after the Second World War. In various well-known studies, contention was mainly seen as the product of specific psychological states. In Kornhauser's (1961) mass society theory, for example, participation in mass movements, in particular the Nazi party machinery, was a sign of individual anomie, caused by the weakening of social ties in society. For Smelser (1968), collective behavior was argued to be the result of perceived structural strain (e.g. the threat of economic deprivation) due to rapid changes in society that excite feelings of anxiety, fantasy or hostility. Turner and Killian (1959) similarly saw collective behavior as a result of changes in societal conditions, which cause individual uncertainty and collective behaviour through social contagion. 
Probably the best-known micro-explanation for collective contention makes use of the 'relative deprivation' concept. Gurr (1974), for example, argued that individuals decide to engage in political violence when 'their value capabilities are not compatible with their value expectations', namely when they experience 'relative deprivation'. Gurr mainly reacted against the claim that political violence is a simple reaction to 'objective' poverty or hardship, and argued for a 'subjective' grievance account (sense of injustice) of political mobilization. The relative deprivation approach incorporated other well-known theories such as the frustrationaggression theory (Berkowitz, 1965) and Davies' (1962) theory of rising expectations or the 'J-curve' model.

Coleman (1990) illustrated clearly how some of these early motivational approaches to conflict used macro-level relations to underpin their micro-level theories. From his perspective of methodological individualism, however, this is considered to be bad practice, as causal explanation of macro-level phenomena requires that social scientists uncover the micro-level mechanisms via which the macro-link substantiates (Hedström \& Swedberg, 1998). Coleman's boat-diagram (Figure 1) illustrates this point. The most important message of this model is that a macro event X cannot be linked directly to another macro-level outcome Y, but instead presupposes a causal pathway at the micro level. One example given by Coleman to illustrate possible micro and macro-level pathways of causal influence dealt with the empirical finding that revolutions often seemed to occur in contexts of positive social change (cfr. Davies's theory of rising expectations). The counterintuitive macro-level relationship between positive change and revolutions could only be understood by taking the causal pathway via individual-level variables into account: Improved social conditions (Macro X) may lead to frustration among some people in society (Micro X), because they feel relatively deprived and/or excluded from the benefits of progress. In turn, psychological theory suggests that frustration may lead to a higher propensity for aggression (Micro Y), which on aggregation may result in a social outcome such as a revolution (Macro Y). Such a theoretical proposition, therefore assumes that the frustrations of individuals who are not advancing in a society are mobilized, and that these persons will collectively start a revolutionary movement. For methodological individualists, every theoretical macro-macro relation presupposes a micro-level causal process, which needs to be empirically substantiated. Therefore, Davies' theory of rising expectations cannot solely be supported by empirical evidence of the macro-level relation (1), but also needs to be proven by macro-micro (2), micro-micro (3), and micro-macro (4) empirical relations. 


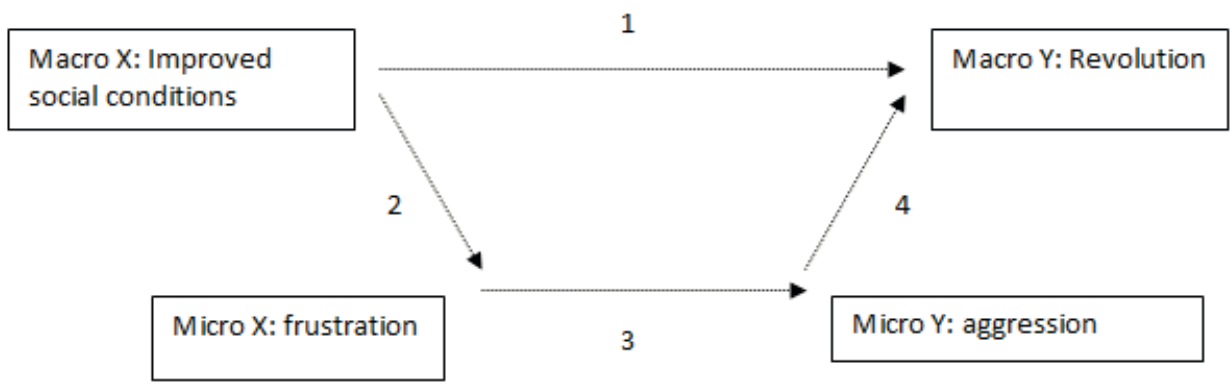

Figure 1: Coleman's Boat

Subsequent research on social movements in the West had a stronger empirical focus on the micro-micro link (relationship 3 in Coleman's boat diagram). This revealed that individuals participating in conflict events were not necessarily the most frustrated or aggrieved, but had access to the resources (capital and labour) needed to mobilize people and organize a movement. These findings gave rise to the resource mobilization paradigm in social movement studies (McCarthy \& Zald, 1977). Similarly, the political process perspective on protest mobilization holds that people take into consideration how authorities will react to opposition (e.g. repression) and only engage in collective action when they perceive an opportunity for this to be successful (McAdam, McCarthy \& Mayer, 1999; Opp, 2009). In other words, empirical focus on the micro-level revealed that grievancebased theoretical assumptions derived from macro-level relations were not always supported.

Further advances in the social movement literature brought attention back to the psychological mechanisms of individual mobilization, but in more complex and nuanced ways than the earlier grievance-based approach had done. Indeed, these mechanisms also came to include emotions (e.g. Jasper and Poulsen, 1995) as well as social identities (e.g. De Weerd and Klandermans, 1999). In sum, methodological advances on protest mobilization in Western contexts have allowed scholars to theorize and unravel further the intricate causal mechanisms underlying mobilization. Studies on conflict in the developing world, however, continue to focus predominantly on individual-level grievance theory, combined with macro-level research designs. 


\section{UNDERSTANDING AND INVESTIGATING ECOLOGICAL FALLACIES IN THE CONFLICT LITERATURE}

\section{Debates on the ecological fallacy}

The concept of an ecological fallacy was defined by Selvin $(1958$, p.613) as a situation in which "relationships between characteristics of individuals are wrongly inferred from data about groups." Indeed, Coleman's boat shows clearly that analyzing relations between macro-level phenomena while empirically ignoring individual-level linkages creates serious risks. The problem of studying ecological correlations knows several sides, however. A first issue is of a statistical nature, and is concerned with reconstituting individual-level relations from aggregated data. In his seminal study on ecological correlations, Robinson (1950) demonstrated how the correlation between the percentage of Blacks and illiteracy rates in American states differs from the individual correlation between race and illiteracy. He concluded that the study of ecological correlations should be abandoned for a research agenda focusing on the properties of individuals. More recently, King (1997) has proposed a statistical method to improve the validity of correlations based on aggregated data for individual-level inferences. A broader understanding of ecological fallacy problems does not only focus on macro-level aggregates of individual-level data (e.g. illiteracy rates or voting percentages), however, but also on variables that are solely measured at the macro-level (e.g. GDP/capita or government debt). The extent to which relationships between macro-level variables, whether they are aggregates or only measured at the macrolevel, can be used to infer individual-level causal mechanisms constitutes the broader theoretical problem of ecological fallacies that concerns us here.

The main argument against macro-level modelling is that macro-level relations do not exist in their own right, but presume an individual-level dynamic that should be investigated empirically (Coleman, 1990; Hedström \& Swedberg, 1998). This position of methodological individualism is also supported by Kittel (2006), who argues that a macro-level relationship between globalization (as measured, for example, by Foreign Direct Investments) and higher social expenditures can be explained or theorized in different ways through the behavior of individuals. However, without micro-level evidence, it is not possible to test these explanations and defend one over the other. According to Kittel, macro-level modelling, hence, holds little theory-testing value. Importantly, this does not mean that individuallevel inferences from macro-relations are necessarily erroneous; instead, the presence of ecological fallacies can only be reliably established by analyzing the hypothesized relations at the individual level.

In a nuanced defense of ecological studies, however, Schwartz (1994) points out that ecological correlations may be more valid than individual-level ones in specific 
circumstances. Firstly, ecological data may be more accurate than individual-level data if the latter are prone to bias (i.e. recall bias and social desirability bias). Drawing on examples from public health research, she argues for instance that sales of alcoholic beverages or rates of abortions may be more useful than statements of alcohol use or an individual's abortion experience. Ecological correlations may, hence, be warranted if there are good reasons to assume individual-level data is prone to error.

Secondly, Schwartz (1994) disputes a methodological individualist viewpoint that all macro-level relations suppose an underlying micro-level causal mechanism and argues that the locus of attention may also be group-level variables and macrolevel processes as such. Ecological data should not necessarily be seen as a rough substitute for individual-level data, but can measure unique contextual concepts and relations. Drawing on an example from Zito (1975 in Schwartz, 1994), who argues that a hung jury does not exist out of indecisive members, yet rather very decided ones who simply disagree, she asserts that some variables only exist at a group level, and that the relationship between such variables may be an important point of scientific interest.

Finally, and related to the previous argument, Schwartz (1994) warns of the 'individualistic fallacy' or the view that macro-level variables do not have explanatory value for the behaviour of individuals in and of themselves. Indeed, context matters for the behaviour of individuals, and ecological or group-level variables may hold explanatory power for micro-level outcomes. It is important to clarify, however, that the individualistic fallacy critique is not necessarily a straightforward defence of macro-level relational studies. While group-level variables may be used as explanatory factors, the dependent variable is generally measured at the individual level. This is the case for multilevel studies in particular (e.g. Coleman, 1990, Greenland, 2001; Subramanian et al., 2009).

Below, we demonstrate how these arguments in favour of and against ecological studies can be applied to civil-war studies and, in turn, recent social disorder studies.

\section{Ecological fallacies in conflict studies}

The ecological fallacy debate has been waged in the fields of epidemiology (e.g. Greenland, 2001; Schwartz, 1994) and sociology (Coleman, 1990; Hedström \& Swedberg, 1998; Kittel, 2006), but unfortunately has not been dealt with in depth in conflict studies. Nevertheless, arguably one of the clearest examples of a possible ecological fallacy in conflict research relates to Collier and Hoeffler's (2002) highly influential paper on greed versus grievance motivations for participation in armed rebellion. In this paper the authors interpret the negative and significant relationship between GDP/capita and the outbreak of civil war as 
evidence in support of their hypothesis that individuals are rational and 'greedy', hence poorer individuals are more likely to join rebel groups because they face lower opportunity costs. Furthermore, they use Polity III regime type and Freedom House scores to investigate whether individual political grievances determine the onset of civil war, but find no statistical association.

According to Collier (2001), the use of macro-level modelling to approach the question of why people join rebel movements is warranted because reliable data about the true motivations of individuals cannot be collected. Therefore, he argues for a focus on 'revealed preferences' by investigating the macro-level. This argument corresponds to Schwartz's (19994) view that individual data are not always reliable. Yet by only relying on the abstract rational choice notion of the 'homo economicus' (Cramer, 2002) $)^{1}$, l'homme moyenne, or the representative agent (Kittel, 2006) at the micro-level, Collier \& Hoeffler (2002) risk wrongfully inferring micro-level dynamics from ecological correlations. Indeed, several studies on rebel motivations have added nuance to Collier's greed argument by relying on survey data (e.g. Langer \& Ukiwo, 2013; Humphreys \& Weinstein, 2008).

In an equally influential study on the determinants of civil war, Fearon and Laitin (2003) make use of many of the same variables, but provide a different interpretation. They find the same significant relationship between the onset of civil war and GDP/ capita, but argue instead that GDP/capita is a measure of a state's strength and its ability to deter rebels. They also use Polity IV scores to measure 'anocracies', regimes that mix democratic and authoritarian characteristics, and find that their presence increases the risk of the outbreak of war. As with GDP/capita, the anocracy variable is seen as a measure of state capacity. Therefore, Fearon \& Laitin (2003) 'resolve' the ecological fallacy problem by theorizing relationships at the macrolevel rather than through individual dynamics, in line with Schwartz's (1994) second argument in defence of ecological correlations. In a subsequent paper, Collier and his collaborators re-theorized their arguments in a similar way (Collier, Hoeffler \& Rohner, 2008). They now argue that it is the opportunity to rebel, operationalized in terms of state weakness and proxied by the level of GDP/capita, which determines which countries will have a civil war and which ones will not. ${ }^{2}$

The papers by Collier and Hoeffler (2002) and Fearon and Laitin (2003) have had a profound impact on both theory and methodology in civil-war studies and are also a source of inspiration for many social disorder studies. Yet the rationale for using macro-level modelling for social disorder studies is less defensible in two important respects. First of all, most studies argue that a relationship between scarcity factors and protest events at the macro-level can be explained through individual economic grievances leading to protest participation (see Section 2). This means that they explicitly rely on micro-level theory rather than macro-level theory as Fearon \& Laitin (2003) and later Collier et al. (2008) did. ${ }^{3}$ Secondly, 
while Collier (2001) argues that macro-level modelling is necessitated by the relative dearth of reliable individual-level data in countries ravaged by civil war, information about individual participation in low-level social disorder events, in particular protests and riots, is commonly gathered through opinion polls and surveys. Especially in western settings, determinants of protest participation have been addressed by means of survey research (Andretta \& della Porta, 2014). These types of data sources may also provide interesting insights in developing settings. Indeed, they could reveal different mobilization dynamics than supposed by macro-level relations, as illustrated below.

\section{EMPIRICAL ILLUSTRATION}

\section{Hypotheses and Data}

Based on examples from quantitative social disorder studies, as well as Collier and Hoeffler's (2002) seminal paper, two theoretical models are formulated in which a macro-macro relationship relies on a micro-level causal link. The macro-macro and micro-micro links are subsequently tested empirically and contrasted. The first model states that poorer countries are likely to witness more protest events, because poorer, and hence more aggrieved, people are more likely to engage in protests. The second model holds that less democratic regimes are likely to experience more protests because people who rate their country as not being a democracy are more likely to engage in protests in order to voice their discontent about the lack of political participation, transparency and accountability.

The formulation of these hypotheses is necessarily influenced by data availability. Several datasets on protest and riot events in Africa are currently available, including, for example, the PRIO Urban Social Disturbance in Africa and Asia database (Urdal, 2008), the Social Conflict in Africa Database (SCAD) (Saleyhan at al., 2012), and the Armed Conflict Location and Event Dataset (ACLED) (Raleigh et al., 2010). These datasets are primarily based on news stories and reports (e.g. Keesing's Record of World Events, Lexis-Nexis, AllAfrica etc.) Here we compare ACLED data on protest counts (version 5) with the Afrobarometer survey question on protest participation. ${ }^{4}$ Since the end of the 1990s, the Afrobarometer Project has conducted surveys concerning citizens' political attitudes and behaviour in selected African countries. For the present analyses, data from Round 5 are used. ACLED event counts of protests and riots (as the Afrobarometer question may refer to both) are constructed for the 12-month period prior to the last interview date in any country survey. Events are included if actors are defined as 'Protesters' or 'Rioters'. Events are also limited to events in which protesters and rioters were internal actors (as the Afrobarometer project only questions national citizens). ${ }^{5}$ 
For the macro-level independent variables GNI per capita (World Development Indicators) and the Polity IV regime-type scores are used. Data are taken for the year of the last interview date of a country's Afrobarometer survey. At the microlevel, a person's individual welfare and the degree to which a respondent sees his/her country as a democracy are used. Both variables are derived from the Afrobarometer surveys. Table 1 describes all variables.

Table 1: Macro and micro variables

\section{MACRO-LEVEL}

\begin{tabular}{|c|c|c|c|}
\hline Variable & Description & \multicolumn{2}{|l|}{ Measurement } \\
\hline $\begin{array}{l}\text { ACLED: } \\
\text { Protests and } \\
\text { riots }\end{array}$ & \multicolumn{3}{|c|}{$\begin{array}{l}\text { A protest describes a non-violent, group event counts } \\
\text { public demonstration, often against } \\
\text { a government institution. Rioting is } \\
\text { a violent form of demonstration. }\end{array}$} \\
\hline $\begin{array}{l}\text { GNI/capita } \\
\text { (WDI) }\end{array}$ & $\begin{array}{l}\text { GNI/capita, PPP, current international } \\
\$(2015)\end{array}$ & \multicolumn{2}{|l|}{ Natural logarithm } \\
\hline $\begin{array}{l}\text { Regime type } \\
\text { (Polity IV) }\end{array}$ & $\begin{array}{l}\text { The POLITY score is computed by sub- } \\
\text { tracting the AUTOC (autocracy) score } \\
\text { from the DEMOC (democracy) score }\end{array}$ & \multicolumn{2}{|c|}{$\begin{array}{l}\text { - Scale from }+10 \text { (strongly democratic) to }-10 \\
\text { (strongly autocratic) }\end{array}$} \\
\hline \multicolumn{4}{|c|}{ MICRO-LEVEL: Survey data } \\
\hline Variable & Question wording & Answer scales ${ }^{a}$ & $\begin{array}{l}\text { Recoded answer } \\
\text { scales }\end{array}$ \\
\hline $\begin{array}{l}\text { Individual } \\
\text { protest } \\
\text { participation }\end{array}$ & $\begin{array}{l}\text { Here is a list of actions that people } \\
\text { sometimes take as citizens. For each of } \\
\text { these, please tell me whether you, per- } \\
\text { sonally, have done any of these things } \\
\text { during the past year. If not, would you } \\
\text { do this if you had the chance: Attended } \\
\text { a demonstration or protest march? }\end{array}$ & $\begin{array}{l}0=\text { No, would never } \\
\text { fo this } \\
1=\text { No, but would do if } \\
\text { had the chance } \\
2=\text { Yes, once or twice } \\
3=\text { Yes, several times } \\
4=\text { Yes, often }\end{array}$ & $\begin{array}{l}0=\text { No } \\
1=\text { Yes }\end{array}$ \\
\hline $\begin{array}{l}\text { Individual eco- } \\
\text { nomic index }\end{array}$ & $\begin{array}{l}\text { Over the past year, how often, if ever, } \\
\text { have you or anyone in your family gone } \\
\text { without: } \\
\text { Enough food to eat? } \\
\text { Enough clean water for home use? } \\
\text { Medicines or medical treatment? } \\
\text { Cooking fuel? } \\
\text { A cash income? }\end{array}$ & $\begin{array}{l}0=\text { Never } \\
1=\text { Just once or twice } \\
2=\text { Several times } \\
3=\text { Many times } \\
4=\text { Always }\end{array}$ & $\begin{array}{l}\text { Economic index: sum of } \\
5 \text { items * }(-1) \\
\text { (Note: multiplied by }-1 \\
\text { to match the direction } \\
\text { of the variable to GNI/ } \\
\text { capita) }\end{array}$ \\
\hline $\begin{array}{l}\text { Individual } \\
\text { democracy } \\
\text { rating }\end{array}$ & $\begin{array}{l}\text { Democracy today: } \\
\text { In your opinion how much of a democ- } \\
\text { racy is Benin/Ghana/... today? }\end{array}$ & $\begin{array}{l}\text { 1=Not a democracy } \\
2=A \text { democracy, with } \\
\text { major problems } \\
\text { 3=A democracy, but } \\
\text { with minor problems } \\
4=A \text { full democracy }\end{array}$ & $\begin{array}{l}0=\text { Not a democracy or } \\
\text { one with major prob- } \\
\text { lems } \\
1=\text { a democracy or one } \\
\text { with minor problems }\end{array}$ \\
\hline
\end{tabular}

a. Missing cases, refusals, and 'don't know' answers are left out of the analyses. 
The critical analysis of the common practice of testing micro-level (grievance) theory by making use of macro-level data and analysis relies on a comparison of the direction and significance of the macro-macro relations (arrow 1 in Coleman's boat) with the micro-micro-relations (arrow 3 in Coleman's boat) that are theoretically associated with them. In the two theoretical models used here, GNI/capita and Polity IV are the 'Macro X' variables, while protest event count is the 'Macro $\mathrm{Y}^{\prime}$ '. For the underlying micro-relations, individual economic index and individual democracy rating are the 'Micro $\mathrm{X}$ ' with protest participation as 'Micro $\mathrm{Y}$ '. After demonstrating that different relations may hold on the macro-macro and micromicro levels, we further analyze the reasons for this mismatch by focusing on the macro-micro (arrow 2) and micro-macro (arrow 4) relations.

Of course, additional factors besides the ones used in the analyses can determine protest event occurrence as well as participation. Most quantitative social disorder studies use quite a number of control variables. At the individual level as well, factors such as gender and educational level can be significant predictors of protest participation. However, the models are limited to the variables described above to allow testing them in a straightforward manner.

Finally, it is also important to note that both the survey data and event data can be subject to error. Possible survey errors may be due to recall effects (i.e. difficulties in remembering protest participation in a certain time period) and social desirability bias (the respondent is unwilling to acknowledge protest participation). Event data can be subject to selection bias if not all events which actually occurred are included in the media reports on which event datasets are based (Earl et al., 2004). These problems further attest to the difficulties of modelling and theorizing at different levels of analysis, however, and further contribute to the argument made here.

\section{Results}

First, two models based on macro-level data and two corresponding models based on micro-level data are tested. The total number of observations at the macro-level is 30 , the total number of observations at the micro-level is 42526 . We conduct complete case analyses. Table 2 shows the descriptive statistics.

As the macro-level dependent variable is a count variable, negative binomial regressions are used. For the micro-models, logistic regressions are used in a multilevel framework to account for the country-clustering of the data. Table 3 shows the results of the macro-macro models.

Model 1 reveals a positive relationship between GNI/capita and the number of protest events for the sample of Afrobarometer countries. Following the first theoretical model, this could indicate that because the macro-macro relationship is 
Table 2: Descriptive statistics

\begin{tabular}{lrrccc}
\hline Variable & $\mathbf{N}^{\mathbf{a}}$ & Mean & $\begin{array}{c}\text { Standard } \\
\text { Deviation }\end{array}$ & Minimum & Maximum \\
\hline ACLED event counts & 30 & 52.73 & 108.89 & 0 & 595 \\
In GNI/cap & 30 & 7.86 & 0.91 & 6.59 & 9.60 \\
Polity IV & 30 & 3.40 & 4.60 & -9 & 9 \\
Protest participation & 42526 & 0.09 & 0.30 & 0 & 1 \\
Economic Index & 42526 & -6.58 & 5.017 & -20 & 0 \\
Democracy rating & 42526 & 0.57 & 0.52 & 0 & 1 \\
\hline
\end{tabular}

a. Cape Verde and Mauritius are not included in our analysis because there is no information in ACLED for these countries. Tunisia is also dropped from our analysis because there is no Polity IV score available. Across-weights are applied for the descriptive statistics of the micro-level variables.

Table 3: Macro-macro model results

\begin{tabular}{lcc}
\hline Dependent: ACLED event counts & & \\
\hline & Model 1 & Model 2 \\
\hline In GNI/cap & $0.863^{* * *}$ & $-0.130^{* * *}$ \\
Polity IV & & $4.231^{* * *}$ \\
Constant & $-3.139^{* * *}$ & 30 \\
$\mathrm{~N}$ & 30 & \\
\hline${ }^{* * *} p<.01 ;{ }^{* *} p<.05$ & &
\end{tabular}

not negative as supposed, this means that the micro-micro causal link, namely that poorer people are more likely to participate in protests, is also not supported. Model 2 shows a negative relationship between regime type score and protest events. This could support the second theoretical model and its supposed micro-micro link, namely that people who are dissatisfied with the regime are more likely to protest.

The dangers of supposing micro-level dynamics from macro-level relations are demonstrated in the micro-micro models, however (Table 4). Model 3 shows that a respondent's individual economic index is negatively related to protest participation. The initially hypothesized micro-level dynamic - poorer people are more likely to participate in protests - therefore receives some support from the data. Hence, the macro-level analysis could not be relied upon to inform us about individual beliefs and behaviours. Model 4 reveals that people who rate their country as not being a democracy are also more likely to participate in a protest. Interestingly, this relationship runs in the same direction as the macro-level 
Leila Demarest, Arnim Langer, Bart Meuleman Between fallacy and feasibility?

Dealing with the risk of ecological fallacies in the quantitative study of protest mobilization and conflict

relation. This supports the second theoretical model and also shows that individuallevel assumptions based on macro-level relations are not necessarily incorrect. However, when left untested, they remain tentative and potentially flawed.

Table 4: Micro-micro model results

\begin{tabular}{lcl}
\hline \multicolumn{3}{l}{ Dependent: Afrobarometer protest participation } \\
\hline $\begin{array}{l}\text { Model 3 } \\
\text { Individual economic }\end{array}$ & Model 4 \\
$\begin{array}{l}\text { Individual Democracy } \\
\text { rating }\end{array}$ & $-0.010^{\star *}$ \\
Constant & & \\
Within variance & $-2.448^{\star * *}$ & $-2.249^{* * *}$ \\
Between variance & 3.29 & 3.29 \\
\hline $\mathrm{N}\left(2^{\text {nd }}\right.$ level $)$ & 0.061 & 0.062 \\
\hline $\mathrm{N}$ & 30 & 30 \\
\hline
\end{tabular}

${ }^{* * *} p<.01 ;{ }^{* *} p<.05$

Table 5: Macro-micro model results

\begin{tabular}{lcc}
\hline & $\begin{array}{c}\text { Model 5 } \\
\text { (dep.: Individual } \\
\text { economic index) }\end{array}$ & $\begin{array}{c}\text { Model 6 } \\
\text { (dep.: Individual } \\
\text { democracy rating) }\end{array}$ \\
\hline In GNI/cap & $1.590^{* * *}$ & $0.096^{* * *}$ \\
Polity IV & $-19,074^{* * *}$ & -0.014 \\
Constant & 1.927 & 3.29 \\
Within variance & 18.014 & 0.092 \\
Between variance & 30 & 30 \\
\hline $\mathrm{N}\left(2^{\text {nd }}\right.$ level $)$ & 42526 & 42526 \\
\hline $\mathrm{N}$ & & \\
\hline${ }^{* * *} p<.01 ;{ }^{* *} \mathrm{p}<.05$ & &
\end{tabular}

While the foregoing has demonstrated how different relations may hold on different levels of analysis, we investigate this mismatch further by empirically analyzing how the macro and micro-level are related to each other. Our theoretical models proposed that poorer countries had poorer, more aggrieved people, while less democratic countries had more politically aggrieved people. This causal reasoning corresponds to the second arrow in Coleman's boat. We analyze these relations through multilevel models reported in Table 5. The results appear to 
indicate that, indeed, people are less well off in countries with a lower GDP/capita, and that people are more likely to rate their country as not democratic in countries with low Polity scores. While these relations are not perfect, there is empirical support for the macro-micro links in the theoretical models.

The micro-macro relations in our theoretical models are more difficult to analyze statistically (see Bennink, Croon \& Vermunt, 2013). However, as regression is in essence a correlational analysis, we analyze arrow 4 in Coleman's boat model here through a multi-level model with protest participation as dependent and ACLED event counts as independent. Table 6 shows clearly that there is no relationship between these variables. The hypothesized theoretical relation between protest participation and protest events therefore lacks support. While this may be due to measurement error, there are also important conceptual reasons for the mismatch between both variables. Indeed, the number of protest events is not necessarily linked to a large number of participants, as protest events can be staged by a small number of organizations, with a relatively small, yet highly motivated, group of supporters.

Table 6: Micro-macro model results

\begin{tabular}{lc}
\hline & $\begin{array}{c}\text { Model } 7 \\
\text { (dep.: protest participation) }\end{array}$ \\
\hline ACLED & 0.00009 \\
Constant & $-2.388^{* * *}$ \\
Within variance & 3,29 \\
Between variance & 0,062 \\
\hline $\mathrm{N}\left(2^{\text {nd }}\right.$ level $)$ & 30 \\
\hline $\mathrm{N}$ & 42526 \\
\hline${ }^{* * *} p<.01 ;{ }^{* *} p<.05$ &
\end{tabular}

Given that there is no empirical support for the hypothesized micro-macro link between protest participation and events, we can also deduce that the empirical correspondence of the macro-macro relation between Polity and protest events and the micro-micro relation between perceptions of democracy and protest participation are not due to the hypothesized causal mechanism.

\section{CONCLUSIONS AND LESSONS FOR FURTHER RESEARCH}

This paper has focused on the risk of ecological fallacies in the quantitative study of social disorder events in the developing world. Similar to civil-war studies, many quantitative disorder studies use macro-level modelling techniques to regress event 
data on indicators of resource scarcity for a given country or sub-national area, while at the same time relying on individual-level hypotheses to substantiate this link theoretically. However, leaving these micro-level dynamics unaddressed can pose problems for the validity of the research results. As illustrated empirically by making use of macro- as well as micro-level data, individual relationships inferred from macro-level analyses are not necessarily supported when testing them in their own right.

The rationale for using macro-level empirical data to investigate micro-level processes in quantitative civil-war studies was mainly driven by a lack of reliable individual-level data in these settings. Nonetheless, recent advances in this field of study have emphasized the importance of investigating and gathering data on micro-dynamics (Balcells \& Justino, 2014). For social disorder events as well, further empirical inquiry into individual mobilization processes is necessary. Moreover, data collection in these low-level conflict settings is arguably more feasible.

The study of individual participation in protests and riots in the developing world can in particular draw on the social movement literature, which has, for now, focused predominantly on Western countries. Several survey designs to investigate protests are possible; for example, the study of protest participation in general in a nationally representative survey or the study of protest participation in a specific protest event (Andretta \& della Porta, 2014). The latter can be investigated by conducting a survey during the event or by surveying an area where participants are known to originate from. Cross-national variations in protest participation and the effect of macro-level variables on individual behavior can also be tested via multilevel models (e.g. Christensen, 2016). To fully understand participation, it is also necessary that grievances are questioned (and not inferred from socio-demographic characteristics), as well as social capital (resources), and perceptions of political opportunity structures. These issues can also be addressed in experimental designs (Van Zomeren et al., 2004).

Micro-focused research designs are indeed largely absent from the current literature on social disorder in the developing world. Some examples include Resnick and Casale's (2011) study on protest participation by means of Afrobarometer data, or Scacco's (2008) study of ethnic riots in Jos, Nigeria. Interestingly, both studies provide evidence that resource mobilization and network contacts are important determinants of contentious actions. Hence, in developing settings as well, these theoretical approaches and types of data can improve in-depth understanding of protest mobilization.

The foregoing does not imply that the study of protest events should be abandoned. This macro-level approach may still be defensible if researchers are mainly interested in group-level processes (Schwartz, 1994). Sutton, Butcher, and 
Svensson (2014), for instance, investigate to what extent group-level characteristics of protest events (e.g. their level of organization) lead to a violent response from the state. However, if the underlying theory for a macro-macro relation is situated at the micro-level, the methodological individualist perspective rightly emphasizes the importance that researchers clarify that the underlying individual dynamics are tentative and not tested within the research design. In the same vein, one has to exercise extreme care when inferring causal pathways at the micro-level from macro-level empirical data and associations.

\section{NOTES}

1 In his well-known critique on the work of Collier and Hoeffler, Cramer (2002) argues that Collier makes use of theories based on methodological individualism and, indeed, economic rational choice theory is the starting point of their work. However, Collier and Hoeffler do not use the data and methods prescribed by methodological individualists, such as Robinson and Coleman. By not empirically testing the posited causal relations at the micro-level, Collier and Hoeffler stand far apart from the methodological individualist perspective.

2 It can be argued, however, that this macro-relationship also presupposes an individual link, namely that individuals see and evaluate state capacity and adjust their actions accordingly. This discussion was also held in the social movement literature, where political opportunities are often measured by the researcher at the macro-level and then related to protest events (e.g. Kriesi et al., 1998). Critical voices have argued that this research design neglects the individual and his/her perceptions of political opportunities (McAdam, McCarthy, \& Zald, 1999, p.8; Opp, 2009, pp. 167-171).

3 Some authors also combine micro- and macro-level theory. Hendrix and Salehyan (2012), for instance, argue that rainfall shocks may lead to grievances as well as diminished state capacity.

4 ACLED's protest event definition corresponds closely to the Afrobarometer understanding of protest activity as a public demonstration. For different understandings between event and survey data on protest activity, see Biggs (2015). It is also important to note that if a protest lasts for multiple days, each day is counted as an event in ACLED, which also has implications for assumptions on the number of participants.

5 Some protests are found in the ACLED event category 'Violence against civilians' and not the category 'Protest/Riot'. By relying on actor specifications we, can also include these cases. We also browsed ACLED for events identifying one of the actors as international or with a nationality foreign to the country (based on the Actor and notes variables) and excluded these events from the analyses.

\section{REFERENCES}

Andretta, Massimiliano and Donatella della Porta. 2014. "Surveying Protestors: Why and How." Pp. 308-34 in Methodological Practices in Social Movement Research., edited by D. della Porta. Oxford: Oxford University Press. https://doi.org/10.1093/ acprof:oso/9780198719571.003.0013 
Balcells, Laia and Patricia Justino. 2014. "Bridging micro and macro approaches on civil wars and political violence: issues, challenges, and the way forward." Journal of Conflict Resolution 58(8): 1343-1359. https://doi.org/10.1177/0022002714547905

Bennink, Margot, Marcel A. Croon, and Jeroen K. Vermunt. 2013. "Micro-macro multilevel analysis for discrete data: a latent variable approach and an application on personal network data." Sociological Methods \& Research 42(4): 431-457. https://doi.org/10.1177/0049124113500479

Berkowitz, Leonard. 1965. "The concept of aggressive drive: some additional considerations." Advances in Experimental Psychology 2: 301-329. https://doi.org/10.1016/ S0065-2601(08)60109-4

Bernauer Thomas and Nils P. Gleditsch. 2012. "New event data in conflict research." International Interactions 38(4): 375-381. https://doi.org/10.1080/03050629.2012. 696966

Biggs, Michael. 2015. "Has protest increased since the 1970s? How a survey question can construct a spurious trend." British Journal of Sociology 66(1): 141-162. https://doi.org/10.1111/1468-4446.12099

Buhaug, Halvard and Henrik Urdal. 2013. "An urbanization bomb? Population growth and social disorder in cities." Global Environmental Change 23: 1-10. https://oi. org/10.1016/j.gloenvcha.2012.10.016

Christensen, Henrik Serup. 2016. "All the same? Examining the link between three kinds of political dissatisfaction and protest." Comparative European Politics 14(6): 781-801. https://doi.org/10.1057/cep.2014.52

Coleman, James S. 1990. Foundations of Social Theory. Cambridge: Harvard University Press.

Collier, Paul. 2001. "Economic Causes of Civil War and Their Implications For Policy." Pp. 134-62 in Turbulent Peace: The Challenges of Managing International Conflict, edited by P.R. Aall, F.O. Hampson, and C.C. Crocker. Washington, D.C.: United States Institute for Peace Press,.

Collier, Paul and Anke Hoeffler. 2002. "Greed and Grievance in Civil War." Centre for the Study of African Economies Working Paper Series 2002-01.

Collier, Paul, Anke Hoeffler and Dominic Rohner. 2008. "Beyond greed and grievance: feasibility and civil war." Oxford Economic Papers 61: 1-27. https://doi.org/10.1093/ oep/gpn029

Cramer, Christopher. 2002. "Homo economicus goes to war: methodological individualism, rational choice and the political economy of war." World Development 30(11): 1845-1864. https://doi.org/10.1016/S0305-750X(02)00120-1

Davies, James C. 1962. "Toward a theory of revolution." American Sociological Review 27(1): 5-19. https://doi.org/10.2307/2089714

De Weerd, Marga and Bert Klandermans. 1999. "Group identification and political protest: farmers' protest in the Netherlands." European Journal of Social Psychology 29(8): 1073-1095. https://doi.org/10.1002/(SICI)1099-0992(199912)29:8\%3C1073::AIDEJSP986\%3E3.0.CO;2-K

Earl, Jennifer, Andrew Martin, John D. McCarthy, and Sarah A. Soule. 2004. "The use of newspaper data in the study of collective action." Annual Review of Sociology 30: 65-80. https://doi.org/10.1146/annurev.soc.30.012703.110603 
Fearon, James D. and David D. Laitin. 2003. “Ethnicity, insurgency, and civil war.” American Political Science Review 97(1): 75-90. https://doi.org/10.1017/S0003055403000534

Gleditsch, Kristian S., Nils Metternich and Andrea Ruggeri. 2014. "Data and progress in peace and conflict research." Journal of Peace Research 51(2): 301-314. https://doi.org/10.1177/0022343313496803

Greenland, Sander. 2001. "Ecologic versus individual-level sources of bias in ecologic estimates of contextual health effects." International Journal of Epidemiology 30(6): 1343-1350. https://doi.org/10.1093/ije/30.6.1343

Gurr, Ted R. 1974. Why Men Rebel. Princeton: Princeton University Press.

Hedström, Peter and Richard Swedberg. 1998. Social mechanisms: An analytical approach to social theory. Cambridge: Cambridge University Press. https://doi. org/10.1017/CBO9780511663901

Hendrix, Cullen S. and Stephan Haggard. 2015. "Global food prices, regime type, and urban unrest in the developing world." Journal of Peace Research 52(2): 143-157. https://doi.org/10.1177/0022343314561599

Hendrix, Cullen S. and Idean Salehyan. 2012. "Climate change, rainfall, and social conflict in Africa.”JournalofPeaceResearch49(1):35-50.https://doi.org/10.1177/0022343311426165

Humphreys, Macartan and Jeremy M. Weinstein. 2008. "Who fights? The determinants of participation in civil war." American Journal of Political Science 52(2): 436-455. https://doi.org/10.1111/j.1540-5907.2008.00322.x

Jasper, James M. and Jane D. Poulsen. 1995. "Recruiting strangers and friends: moral shocks and social networks in animal rights and anti-nuclear protests." Social Problems 42(4): 493-512. https://doi.org/10.2307/3097043

King, Gary. 1997. A Solution to the Ecological Inference Problem: Reconstructing Individual Behavior From Aggregate Data. Princeton: Princeton University Press.

Kittel, Bernhard. 2006. "A crazy methodology? On the limits of macro-quantitative social science research." International Sociology 21(5): 647-677. https:/doi. org/10.1177/0268580906067835

Kriesi, Hans-Peter, Ruud Koopmans, Jan W. Duyvendak, and Marco G. Giugni. 1998. New social movements in Western Europe: a comparative analysis. Minneapolis: University of Minnesota.

Kornhauser, William. 1961. The Politics of Mass Society. Glencoe: Free Press.

Langer, Arnim and Ukoha Ukiwo. 2011. Horizontal Inequalities and Militancy: The Case of Nigeria's Niger Delta. Pp 231-50 in Overcoming the Persistence of Inequality and Poverty, edited by V. FitzGerald, J. Heyer, and R. Thorp, eds.. London: Palgrave Macmillan. https://doi.org/10.1057/9780230306721_10

McAdam, Douglas. 1982. Political Process and the Development of Black Insurgency, 1930-1970. Chicago: University of Chicago Press.

McAdam, Douglas, John D. McCarthy, and Mayer N. Zald. 1999. "Introduction." Pp. 1-22 in Comparative Perspectives on Social Movements: political opportunities mobilizing structures, and cultural framings, edited by D. McAdam, J.D. McCarthy, and Z.N. Mayer. Cambridge: Cambridge University Press,.

McCarthy, John D., and Mayer N. Zald. 1977. "Resource mobilization and social movements: a partial theory." American Journal of Sociology 82(6): 1212-1241. https://doi.org/10.1086/226464 
Dealing with the risk of ecological fallacies in the quantitative study of protest mobilization and conflict

Miguel, Edward, Shanker Satyanath and Ernest Sergenti. 2004. "Economic shocks and civil conflict: an instrumental variables approach." Journal of Political Economy 112(4): 725-753. https://doi.org/10.1086/421174

Opp, Karl-Dieter. 2009. Theories of Political Protest and Social Movements: a Multidisciplinary Introduction, Critique, and Synthesis. London: Routledge. https://doi.org/10.4324/9780203883846

Raleigh, Clionadh, Hyun J. Choi and Dominic Kniveton. 2015. "The devil is in the details: An investigation of the relationships between conflict, food price and climate across Africa." Global Environmental Change 32: 187-199. https://doi.org/10.1016/j. gloenvcha.2015.03.005

Raleigh, Clionadh, Andrew Linke, Håvard Hegre and Joakim Karlsen. 2010. "Introducing ACLED-Armed Conflict Location and Event Data." Journal of Peace Research 47(5): 1-10. https://doi.org/10.1177/0022343310378914

Ralph H. Turner and Lewis M. Killian. 1959. Collective Behavior. Englewood Cliffs: Prentice Hall.

Resnick, Danielle and Daniela Casale. 2011. The political participation of Africa's youth: turnout, partisanship, and protest. UNU-WIDER Working paper 2011/56.

Robinson, William S. 1950. "Ecological correlations and the behavior of individuals." American Sociological Review 15(3): 351-357. https://doi.org/10.2307/2087176

Salehyan, Idean, Cullen S. Hendrix, Jesse Hamner, Christina Case, Christopher Linebarger, Emily Stull, and Jennifer Williams. 2012. "Social conflict in Africa: A new database." International Interactions 38(4): 503-511. https://oi.org/10.1080/03050629.2012.697426

Scacco, Alexandra. 2008. Who riots? Explaining individual participation in ethnic violence. Working Paper. Available at http://politics.as.nyu.edu/docs/IO/9568/ jobpaper.pdf (accessed 25 February 2017).

Schwartz, Sharon. 1994. "The fallacy of the ecological fallacy: The potential misuse of a concept and the consequences." American Journal of Public Health 84(5): 819824. https://doi.org/10.2105/AJPH.84.5.819

Selvin, Hanan C. 1958. "Durkheim's Suicide and Problems of Empirical Research." American Journal of Sociology 63(6), 607-619. https://doi.org/10.1086/222356

Smelser, Neil 1963. Theory of Collective Behavior. New York: Free Press of Glencoe. https://doi.org/10.1037/14412-000

Smith, Todd G. 2014. "Feeding unrest: Disentangling the causal relationship between food price shocks and sociopolitical conflict in urban Africa." Journal of Peace Research 51(6): 679-695. https://doi.org/10.1177/0022343314543722

Subramanian, SV, Kelvyn Jones, Afamia Kaddour, Nancy Krieger. 2009. "Revisiting Robinson: The perils of individualistic and ecologic fallacy." International Journal of Epidemiology 38(2): 342-360. https://doi.org/10.1093/ije/dyn359

Sutton, Jonathan, Charles R Butcher, and Isak Svensson. 2014. "Explaining political jiu-jitsu: Institution-building and the outcomes of regime violence against unarmed protests." Journal of Peace Research 51(5): 559-573. https://doi. org/10.1177/0022343314531004

Urdal, Henrik. 2004. The devil in the demographics: The effect of youth bulges on domestic armed conflict, 1950-2000. Social Development Papers, $\mathrm{N}^{\circ} 14$, The World Bank.

Urdal, Henrik. 2008. Urban Social Disturbance in Africa and Asia: report on a New Dataset. PRIO Papers. 
Urdal, Henrik and Kristian Hoelscher. 2012. "Explaining urban social disorder and violence: An empirical study of event data from Asian and Sub-Saharan African Cities." International Interactions 38(4): 512-528. https://doi.org/10.1080/030506 29.2012.697427

Van Zomeren, Martijn, Russell Spears, Agneta H. Fischer and Collin W. Leach. 2004. "Put your money where your mouth is! Explaining collective action tendencies through group-based anger and group efficacy" Journal of Personality and Social Psychology 87(5): 649-664. https://doi.org/10.1037/0022-3514.87.5.649

Weinberg, Joe and Ryan Bakker. 2014. "Let them eat cake: Food prices, domestic policy and social unrest." Conflict Management and Peace Science. First online 2 June 2014. https://doi.org/10.1177/0738894214532411

Yeeles, Adam. 2015. "Weathering unrest: The ecology of urban social disturbances in Africa and Asia." Journal of Peace Research 52(2): 158-170. https:/doi. org/10.1177/0022343314557508

\section{Leila Demarest}

I am currently Assistant Professor of African Politics at the Institute of Political Science, Leiden University, Netherlands. My research interests include social movements and political mobilization in Africa, political communication, and quantitative and qualitative social science research methodology. My most recent publications (with Arnim Langer) are 'The study of violence and social unrest in Africa: a comparative analysis of three conflict event datasets' in African Affairs (April 2018) and 'Reporting on electoral violence in Nigerian news media: "Saying it as it is?"' African Studies Review, (first online, March 2019).

\section{Arnim Langer}

I am professor in International Relations at KU Leuven and Director of the Centre for Research on Peace and Development (CRPD) at the Faculty of Social Sciences. Currently, I am also Humboldt Research Fellow at the University of Heidelberg, Germany. I have published extensively on the causes of violent conflict in heterogeneous societies and the challenges to sustainable peacebuilding. Some of my recent publications include 'Conceptualising and Measuring Social Cohesion in Africa: Towards a Perceptions-Based Index' Research (with Frances Stewart, Kristien Smedts and Leila Demarest) in Social Indicators (2017) and 'A General Class of Social Distance Measures' (with Graham Brown) in Political Analysis (2016).

\section{Bart Meuleman}

I am currently Associate Professor and coordinator at the Centre for Sociological Research at the KU Leuven Faculty of Social Sciences. I have published extensively on inter-group relations in Europe and elsewhere, as well as on the statistical analysis of survey data. Recent publications include 'Explaining Cross-National Measurement Inequivalence: A Bayesian Multilevel CFA With Random Loadings' (with Elmar Schlüter), book chapter (2018), and 'Can Incentive Effects in Web Surveys be Generalized to Non-Western Countries? Conditional and Unconditional Cash Incentives in a Web Survey of Ghanaian University Students' (with Arnim Langer and Annelies Blom) in Social Science Computer Review (2018). 